\title{
Assessing the Ability of Disability Organizations: An Interprovincial Comparative Perspective
}

\author{
Mario Levesque \\ Mount Allison University
}

\begin{abstract}
Despite much effort put toward Canadian social policy renewal in the past decade, innovations in programming have been stifled due in large part to a lack of funding and accountability issues. This is clearly evident in the disability policy field related to labour market programming for persons with disabilities where the packaging of programs has continually changed; however, the actual contents have largely remained the same. The focus on federal-provincial dimensions has come to marginalize the role of disability organizations in the process, yet it is these organizations that governments may enter into partnership with in new governance arrangements to foster new programming. This article reviews data from charitable tax returns for the time period 2005-2010 to assess the human, financial, and technological capacity of Canadian disability organizations in five Canadian provinces, in order to implement innovative programming.
\end{abstract}

\section{RÉSUMÉ}

Malgré beaucoup d'efforts au renouvellement de la politique sociale canadienne dans la dernière décennie, les innovations dans la programmation ont été étouffées en grande partie à l'absence de questions de financement et de responsabilité. Cela est très évidente dans le domaine de la politique handicap lié à la programmation du marché du travail pour les personnes handicapées où l'emballage des programmes a constamment changé mais le contenu réel est restés largement pareilles. L'accent sur les dimensions provinciales fédérales est venu à marginaliser le rôle des organisations de personnes handicapées dans le processus, mais ce sont ces organismes que les gouvernements peuvent entrer en partenariat avec de nouveaux modes de gouvernance pour favoriser la nouvelle programmation. Cet article examine les données de bienfaisance des déclarations de revenus pour la période 2005-2010 pour évaluer les capacités humaines, financières et technologiques des organisations de personnes handicapées canadiennes dans cinq provinces canadiennes à mettre en œuvre des programmes novateurs.

Keywords / Mots clés : Disability; Policy capacity; Disability associations; Policy change; Canada / Handicap; Capacité politique; Les associations de personnes handicapées; Changement de politique; Canada 


\section{INTRODUCTION}

The lack of innovation in labour market programming for persons with disabilities in Canada has been well documented (HRSDC, 2008; Graefe \& Levesque, 2010). Efforts to move from the delivery of broad vocational programming to innovative and targeted measures that prepare persons with disabilities for entry into the labour market have been met with limited success in that there have been few new programs introduced. Rather, the past ten years have mainly seen the repackaging or continuation of programs long established under the Vocational Rehabilitation Development Program (HRSDC, 2010). Exactly how such repackaging or continuation of old programs can meet current needs of persons with disabilities is unclear; a point stressed by many front line service workers and disability organizations (Graefe \& Levesque, 2006, 2010). These results are surprising given the significant efforts the federal and provincial governments have expended at renewing the Canadian social union since 1995, including negotiation of the Social Union Framework Agreement (SUFA) and various social policy agreements (e.g., Labour Market Programming for Persons with Disabilities) (Telford, Graefe, \& Banting, 2008).

Two main reasons have been put forth to explain the lack of "on the ground" changes: federalism and funding (Boismenu, 2006; Graefe \& Levesque, 2006). Simply put, Canadian federal and provincial governments have been caught in debates surrounding constitutional jurisdictions and accountability mechanisms. The fact that labour market programming for persons with disabilities has attracted little funding, especially when compared to the early learning and child care fields (Friendly \& White, 2008), has further complicated matters. The result has been a stymieing of learning and innovation. Yet there have been few incentives to innovate, given the lack of competition for program and service provision. Hence, old programs have been repackaged to capture changing funding priorities, with provinces holding a virtual monopoly on the provision of services for persons with disabilities, including those for labour market programming (Prince, 2004). This provincial response is not unusual and is consistent with the division of powers under Canada's constitution, which assigns provinces jurisdiction for social programs.

This narrow interpretation of the situation ignores Canada's rich history of federal funding of interest groups to provide services in areas of provincial jurisdiction in order to achieve Pan-Canadian social policy goals (Graham \& Phillips, 1997; Lindquist, 2005). The direct funding of disability organizations by the federal government continues to this day, albeit on a more limited scale. For example, the federal government currently provides approximately $\$ 30$ million per year through the Opportunities Fund to disability organizations for innovative programming for persons with disabilities who would otherwise not qualify for other programs (HRSDC, 2008). In doing so, the federal government is recognizing limitations in current programs and the broader situation. The provinces and the federal government seem to be locked in a "tussle" with each other, and programming for persons with disabilities is caught in the crosshairs (Prince, 2004; Bach, 2002; Hanes \& Moscovitch, 2002). It is simplistic to think that more federal monies provided to the provinces alone would help matters. If that were the case, then Canada's healthcare woes would have long been solved (Commission on the Future of Health Care in Canada, 2002). Instead, the real culprit may be the lack of competition the provinces currently face given its lock on the provision of these services (Powers, Sowers, \& Singer, 2006; Weaver, 1994). To unleash innovation, the position advanced in this article is for the federal government to facilitate an innovative environment by recouping its proud tradition of directly funding civil society groups to meet social goals. However, in doing so, the ability of disability organizations to fulfil this innovative programmatic role is questioned. 
The operational definition of "innovation" used in this research is relatively broad, and refers to a program or policy that is new to the state adopting it; can be shallow, intermediate, or deep; is often evolutionary and adaptive; and may occur at any level of governance (Walker, 1969; Desveaux, Lindquist, \& Toner, 1994; Golden, 1990; Zegans, 1992). Combining employment programs for persons with disabilities from various government initiatives into one portfolio in order to claim federal funding, as was done by Prince Edward Island, does not qualify here as innovative, given that no new programs were developed and existing programs were repackaged and continued (Graefe \& Levesque, 2010). Alternatively, the enhancement of labour market programming, such as an increase in the number or length of time that services are offered, would be considered innovative given such enhancements would be new to the state adopting it (even though such changes may not be the most provocative).

This article assesses the capacity of disability organizations to be vehicles for delivering innovative labour market programs for persons with disabilities. The term "disability organizations" is defined here as nongovernmental organizations that provide services such as employment preparation and training and related services for persons with disabilities (see Tables $1 \mathrm{a}$ and $1 \mathrm{~b}$ ). In essence, it is a subset of the broad category of "interest organizations," which Hendriks (2006) defines to include "elite and active policy actors such as stakeholders, pressure groups, lobby groups, representative organizations, secondary associations, activists, scientists, government agencies, and corporations" yet excludes political parties (p. 572). The article proceeds in three parts. Methodologies used in the investigation are first profiled, followed by a contextual overview of disability organizations and policy in Canada. Capacity issues surrounding disability organizations are then assessed and discussed.

\section{METHODOLOGY}

This article is a Canadian case study that compares two traditionally have provinces (Ontario and Alberta), with three traditionally have not provinces (Newfoundland and Labrador, Nova Scotia, and New Brunswick) to examine similarities and differences in capacity that may exist among select disability organizations. Such a comparison recognizes the fact that disability organizations operate in (and depend on) provinces with different financial capacities, which may provide organizations with different limitations and opportunities. A province is labelled as being have or have not depending on whether or not it receives federal equalization payments. These payments are made to provinces whose fiscal capacity is under the national average in order to bring them up to a standard whereby they may then deliver similar services at similar levels of taxation (Bakvis, Baier, \& Brown, 2009). A province that receives equalization payments is considered to be a have not province, while a province that does not receive equalization payments is termed a have province. The descriptor "traditionally" is used in recognition of the fact that since 2009-2010 Ontario has received equalization payments from Ottawa thus becoming a have not province, while the exact opposite situation has occurred with Newfoundland and Labrador-it is now a have province (Finance Canada, n.d.). However, the provinces are grouped into their traditional categories to reflect the time period of study 2005-2010, to stay consistent with earlier work highlighting funding impediments (e.g., Graefe \& Levesque, 2010), and the fact that the recent changes in financial status will not yet have had adequate time to trickle down to disability organizations and dramatically alter finances.

Disability organizations selected for examination are all registered charities under the Canada Revenue Agency (CRA) regulations to facilitate data accumulation. Charitable tax returns were used to obtain a snapshot of disability organizations. Yearly charitable returns are filed with the CRA and made available to the public via the Charities and Giving website, thus facilitating data collection (see http://www.cra-arc.gc.ca/chrts-gvng//stngs/menueng.html). The information is, however, not "necessarily" verified thus bringing its reliability into question (Canada 
Revenue Agency, 2011). Registered charities must limit their political advocacy work on a sliding scale between $20 \%$ and $10 \%$ of their resources. Organizations with an annual revenue in excess of $\$ 200,000$ are limited to a $10 \%$ allocation of resources to political activities, while registered charities with an annual income of less than $\$ 50,000$ may allocate up to $20 \%$ of this revenue toward political activities (Canada Revenue Agency, 2003). Hence, disability organizations profiled herein primarily focus on service provision.

The disability organizations selected for review were first identified through website searches of the "links" pages of various disability organizations and government websites. Additional organizations were identified through Internet searches. This facilitated the development of preliminary lists for the selection of disability organizations, which were based on a convenience sample along three axes: employment services, assistive devices, and hearing services.

Quantitative data gleaned from the charitable tax returns for the years 2005-2010 was gathered to assess issues of capacity. Capacity is defined in this research as the human, financial, and technological resources of a disability organization. Human resources refer to the average number of employees and the ratio of full-time and part-time employees. Financial resources include the ability of organizations to meet their short-term obligations (liquidity ratio), an assessment of their main funding sources and expenditures, as well as their ability to raise funds (fundraising ratio). Technological resources refer to the amount invested in equipment, computers, vehicles, and furniture. It does not include land and buildings. A forensic review of selected disability organizations is not the goal of this examination, but rather it is to provide a snapshot of the relative health or vibrancy of disability organizations in order to gauge whether such organizations in traditionally have or have not provinces face similar capacity issues, and whether such issues are consistent across three specific subsectors-employment services, assistive devices, and hearing services.

Having the capacity to deliver innovative programs is dependent on factors beyond an organization's human, financial, and technological assets, such as social capital (Putnam, 2000). People and infrastructure are needed to deliver programs, as well as sufficient financial resources to develop and refine programs. Adequate financial resources are required if implementation difficulties arise and additional investment is required to overcome them. To be sure, adequate human, financial, and technological resources do not guarantee a quality or innovative program (especially if the program is poorly designed) but may increase its likelihood (Damanpour \& Schneider, 2009; Satterthwaite, 2002; Bull \& Bane, 2001; Mulroy \& Shay, 1997).

The quantitative profile was then compared with interview data provided by officials from a sample of the disability organizations studied in order to evaluate its congruence. A total of six semi-structured interviews were conducted with content analyses of interview transcriptions revealing major themes for comparison.

\section{CONTEXTUAL OVERVIEW: DISABILITY ORGANIZATIONS AND POLICY IN CANADA}

\section{Valuing disability organizations}

A broad look at disability organizations conceived as voluntary and community organizations involved in service delivery and/or advocacy work on behalf of a specific clientele (White, 2005) finds that they are important conduits for learning, which leads to a vibrant and engaged citizenry over the course of one's life (Canadian Centre on Disability Studies, 2002; Eldson, Reynolds, \& Steward, 1995; Putnam, 2000). These organizations represent wide constituencies and are, as such, means of inclusion, representation, and participation (Meadowcroft, 2004). Gouthro (2010) has shown how people turn to community organizations at transition points in their lives for services either they or a family member need. Combined with the fact that community care is often considered 
ideal, given the importance of independence and citizenship as entitlement to rights and justice (Bron, 2003; Peter, Spalding, Kenny, Conrad, McKeever, \& Macfarlan, 2007), one can see how community organizations contribute to the health of a community in many ways including employment, education, psychologically, and culturally (Gouthro, 2010).

A narrower focus on disability organizations finds a similar result. It is through the engagement of disability organizations that governments acquire information, dispel myths, and enhance the credibility of their policy or services. At the same time, the disability community benefits in the form of expanded inclusion, increased civic capacity, and sense of citizenship (Prince, 2010; Hendriks, 2006; Mansbridge, 1992). As a Canadian Centre on Disability Studies (CCDS) (2002) study found, a common public understanding of disability issues is crucial to the advancement of a disability policy agenda. This underscores the emancipatory role social enterprises may have on persons with disabilities. That is, in addition to their social purpose, organizations generate economic value relating to the production of goods and services, employment of persons with disabilities, and asset ownership (Quarter \& Mook, 2010; Quarter, Mook, \& Armstrong, 2009; Mook, Quarter, \& Ryan, 2010).

\section{Policy context}

Disability organizations can be seen as an integral part of society, yet over the past 40 years their relationships with governments have ebbed and flowed (Roberts, 2001). As the welfare state enlarged in the $20^{\text {th }}$ century, voluntary organizations increasingly became involved in both advocacy and service delivery (Graham \& Phillips, 1997). This is seen in the disability policy field where disability organizations deliver key vocational training activities. Governments at the time were the main funders of these programs, which included funds to meet operational costs. By the 1980s, some organizations came under scrutiny for financial irregularities, and a decade later, while facing unprecedented high debt levels, the federal government unilaterally made deep cuts to transfers to the provinces for health and social programs and discontinued operational grants to disability organizations (White, 2008). The new norm became one of contracting with governments and strict new accountability measures (Larner, 2000). Disability organizations, like others, were now competing against each other for contracts through tendering processes, which worked against their previous collaborative behaviour (Eakin, 2002; Cloutier-Fisher \& Skinner, 2004). This new climate, in particular, the loss of core operational funding, was devastating for organizations and many ceased to exist (White, 2008; Cardozo, 1996).

This crisis in the voluntary sector led to developments on two fronts. On the first front, organizations came together to address accountability and funding issues, yet these efforts were co-opted by the Liberal government's 1999-2004 Voluntary Sector Initiative (VSI), (Panel on Accountability and Governance in the Voluntary Sector, 1999). This initiative minimized or dismissed funding issues (White, 2005) and tried to legitimize the federal government's policy direction by committing it to consider the impact of its actions on voluntary community organizations (Treasury Board Secretariat, 2002). This recognition was a hollow victory at best, given the lack of funding discussions and that the process was captured by elite organizations-on the ground organizations that provided services were not involved in the process (Brock, 2003; Phillips, 2001; Panel on Accountability and Governance in the Voluntary Sector, 1999).

On the second front, the severe federal budgetary cutbacks in the 1990s, the failed attempts at constitutional change (Meech Lake and Charlottetown Accords), and the subsequent 1995 Québec referendum on sovereignty, pressured the federal government to demonstrate the positive workings of the federation through non-constitutional means (Young, 1999; Lazar, 1998). Broad framework agreements were developed, aimed at disentangling responsibilities and elaborating new rules to direct intergovernmental relations. The 1999 Social Union Framework Agreement (SUFA) was one such agreement. SUFA was a significant document in that the 
federal government conceded that they would consult the provinces before spending in their areas of constitutional jurisdiction. In return, the provinces acknowledged that the federal government could spend in areas of provincial jurisdiction (Government of Canada, 1999). This pattern of cross-fertilization of jurisdictions has since waned under successive Harper Conservative governments with its emphasis on the provision of "no strings attached" funding to the provinces as they embrace a more classical model of Canadian federalism (e.g., healthcare; Stephen Harper Interview by Peter Mansbridge, January 16, 2012). However, it is from this framework agreement, the SUFA, which several social policy agreements followed such as Labour Market Programming for Persons with Disabilities.

\section{Labour market programs for persons with disabilities}

For persons with disabilities, changes to labour market programs were a long time coming. Vocational rehabilitation and training was the focus under the Vocational Rehabilitation of Disabled Persons Act (VRDP) from 1961-1997. While expansive in orientation in that it included support for sheltered workshops, employment research aid, and respite services, the focus was on a custodial care model and not one of independent living or full inclusion into society. Under the VRDP, the federal and provincial governments entered into two- to threeyear cost-sharing agreements to deliver various programs. Cost sharing was 50:50, until 1994 when the federal government capped its contribution as part of the 1994 Program Review (Kroeger, 1996; Phillips, 1995).

A series of reports in the 1980s and 1990s challenged the custodial care model, and culminated in the 1998 In Unison report (Burns \& Gordon, 2011; Graefe \& Levesque, 2010). This document elaborated a clear vision for persons with disabilities in advancing their full participation in society. To meet this end, changes were required in disability supports, employment preparation, and income supports (Government of Canada, 1998). Foreshadowing this change in philosophy and to meet the employment preparation pole, the Multilateral Framework for Employability Assistance for People with Disabilities (EAPD) was negotiated between the federal and provincial governments in 1997, along with five-year bilateral agreements (1998) (Government of Canada, 1997; Human Resources Development Canada , 2002). The federal contribution of 50\% was capped at $\$ 190$ million per year and elaborate accountability provisions surrounding the preparation and sharing of annual plans and reports were introduced. The range of services funded under the EAPDs was reduced and funding for sheltered workshops and addictions services was terminated. By all accounts, the EAPDs were of limited success. Programs largely remained the same, and addictions services and sheltered workshops continued to be funded (Graefe \& Levesque, 2010, forthcoming). The new accountability provisions were a point of constant friction between federal and provincial officials, given that annual plans had to be reviewed and approved by federal officials, while reporting requirements proved to be onerous (Graefe \& Levesque, 2006, 2010). Further changes were required.

The successor agreement, the Multilateral Framework for Labour Market Agreement for Persons with Disabilities (2003), and its bilateral agreements (2004) have proven to be no better (Graefe \& Levesque, 2010, forthcoming). These two-year agreements, continually renewed and set to expire in 2012, continued the focus on employability. That is, the focus remained on the design and delivery of a suite of employment programming, including education and training for persons with disabilities (Government of Canada, 2003). The provinces received increased flexibility in reporting requirements and a slim increase in yearly funding from the federal government (up to $\$ 230$ million per year). An extensive review of three have not provinces (i.e., financially challenged; Nova Scotia, New Brunswick, and Prince Edward Island) and two have provinces (i.e., financially able; Ontario, and Alberta) found that little program innovation and learning had occurred. When it did occur, as in limited cases with the have provinces, it was due to decisions taken and increases in funding by provincial governments. For the have not provinces, ineligible programs such as sheltered workshops and addictions services continued to be funded and 
no new programs were developed. In essence, new monies were used to fund existing programs to ensure their continuation. More broadly, funding has proved to be insufficient, with officials from disability organizations stating that much more could be done if only jurisdictional battles were set aside and funding increased (Graefe \& Levesque, 2010).

\section{Overcoming the jurisdictional impasse}

While enhanced funding may well help improve matters, little may be achieved if additional monies are directed to a monopoly provider. Such is the current situation in Canada, with the provinces given preeminence in the social policy realm. Few incentives exist for the provinces to innovate given the lack of competition they face for the provision of services for persons with disabilities. Coupled with the lack of a unified voice from the disability community (Elson, 2011), the provinces have had wide latitude for disability related programming. Enhanced or redirecting existing (some) federal funding, as is currently done with the Opportunities Fund, directly to disability organizations can challenge existing provincial monopolies on labour market programming for persons with disabilities by fostering an innovative environment.

The direct federal funding of interest groups is not without precedent. The Opportunities Fund (OF) could serve as a template for use by the federal government. Since its inception in 1997, the Opportunities Fund has helped persons with disabilities to "prepare for, obtain, and maintain employment or self-employment" (Human Resources and Social Development Canada, n.d.). Individuals, employers, or organizations apply directly to the federal government for funds to support employment activities such as to increase their job skills or to integrate into the workforce. Funding is targeted for persons with disabilities who are not eligible for Employment Insurance benefits. The OF is small and has been capped at approximately $\$ 30$-million annually though it has received an additional \$30-million over three years announced as part of Budget 2012 (Government of Canada, 2012). While appreciative of the funding, disability organizations have observed that the fund is limiting in that only national projects (i.e., delivered in at least three provinces) qualify for funding and that the funding is for short-term projects only (i.e., maximum three years) and meet strict accountability requirements (Graefe \& Levesque, 2010; Human Resources and Social Development Canada, n.d.; Rioux \& Prince, 2002). Provinces to date have not been concerned about this program given the relatively small dollar amounts involved (Graefe \& Levesque, 2010). Hence, a mechanism exists to foster a more productive environment to spur innovation and learning yet it calls into question the capacity of disability associations to deliver such innovative programming.

\section{PROFILE OF DISABILITY ORGANIZATIONS}

Charitable returns for 15 disability organizations were reviewed for the years 2005-2010. This consisted of three disability organizations in each of the five provinces selected for the study (Newfoundland and Labrador, Nova Scotia, New Brunswick, Ontario, and Alberta). For each province, care was taken to select a representative organization along three axes: employment services, assistive devices, and hearing services. Tables 1a and 1b list the charities studied and provide a brief profile of their main program areas and clients as identified in their charitable returns. 


\section{Table 1a. Disability organizations selected for study, program areas, have not provinces}

\begin{tabular}{|c|c|c|c|}
\hline Province & $\begin{array}{l}\text { Employment } \\
\text { services }\end{array}$ & $\begin{array}{l}\text { Assistive } \\
\text { devices }\end{array}$ & $\begin{array}{l}\text { Hearing } \\
\text { services }\end{array}$ \\
\hline $\begin{array}{l}\text { Newfoundland } \\
\text { and Labrador }\end{array}$ & Coalition of Persons with Disabilities & $\begin{array}{l}\text { Learning Disabilities } \\
\text { Association of NL }\end{array}$ & $\begin{array}{l}\text { Canadian Hard of } \\
\text { Hearing Association - } \\
\text { NL Inc. }\end{array}$ \\
\hline Program areas: & $\begin{array}{ll}\cdot 40 \% & \text { Advocacy } \\
\cdot 30 \% & \text { Human rights } \\
\cdot 15 \% & \text { Public education } \\
& \text { (multi-disability) }\end{array}$ & $\begin{array}{l}\text { - } 100 \% \text { Literacy } \\
\text { programs }\end{array}$ & $\begin{array}{l}\cdot 75 \% \text { Other } \\
\cdot 10 \% \text { Seniors' services } \\
\cdot 10 \% \text { Support \& } \\
\text { services for charitable } \\
\text { sector }\end{array}$ \\
\hline Nova Scotia & $\begin{array}{l}\text { Affirmative Industry Association of } \\
\text { Nova Scotia }\end{array}$ & Easter Seals Nova Scotia & $\begin{array}{l}\text { Society of Deaf and Hard } \\
\text { of Hearing Nova Scotians }\end{array}$ \\
\hline Program areas: & $\begin{array}{l}\text { - } 100 \% \text { Employment } \\
\text { preparation and training (primarily } \\
\text { mental health clients) }\end{array}$ & $\begin{array}{l}-50 \% \text { Services for } \\
\text { physically or mentally } \\
\text { challenged } \\
\text { - } 20 \% \text { Promotion \& } \\
\text { protection of health } \\
\text { - } 20 \% \text { Employment } \\
\text { preparation \& training }\end{array}$ & $\begin{array}{l}\cdot 60 \% \text { Interpreter \& } \\
\text { note taking services } \\
\cdot 30 \% \text { Services for } \\
\text { physically or mentally } \\
\text { challenged } \\
\cdot 10 \% \text { Literacy } \\
\text { programs }\end{array}$ \\
\hline New Brunswick & $\begin{array}{l}\text { Community Industries Employment } \\
\text { Vocational Association Inc. }\end{array}$ & $\begin{array}{l}\text { Canadian Rehabilitation } \\
\text { Council for the Disabled }\end{array}$ & $\begin{array}{l}\text { South-east Deaf \& Hard } \\
\text { of Hearing Association }\end{array}$ \\
\hline Program areas: & $\begin{array}{l}-90 \% \text { Services for } \\
\text { physically or\& mentally } \\
\text { challenged } \\
\cdot 10 \% \text { Vocational/ } \\
\text { technical training }\end{array}$ & $\begin{array}{l}\cdot 56 \% \text { Services for } \\
\text { physically or mentally } \\
\text { challenged } \\
\cdot 28 \% \text { Summer camps } \\
\cdot 16 \% \text { Support and } \\
\text { services for charitable } \\
\text { sector }\end{array}$ & $\begin{array}{l}\text { - } 80 \% \text { Services for } \\
\text { physically or mentally } \\
\text { challenged } \\
\text { - } 5 \% \text { Cultural } \\
\text { programs, including } \\
\text { heritage languages } \\
\text { - } 5 \% \text { Literacy programs }\end{array}$ \\
\hline
\end{tabular}

Source: Canada Revenue Agency. Charities listings. URL: http://www.cra-arc.gc.ca/chrts-gvng/lstngs/menu-eng.html [February 5, 2011]. 


\section{Table 1b. Disability organizations selected for study, program areas, have provinces}

\begin{tabular}{|c|c|c|c|}
\hline Province & $\begin{array}{l}\text { Employment } \\
\text { services }\end{array}$ & $\begin{array}{l}\text { Assistive } \\
\text { devices }\end{array}$ & $\begin{array}{l}\text { Hearing } \\
\text { services }\end{array}$ \\
\hline Ontario & $\begin{array}{l}\text { LEADS Employment Services } \\
\text { London Inc }\end{array}$ & $\begin{array}{l}\text { Ontario Society For Crippled } \\
\text { Children }\end{array}$ & $\begin{array}{l}\text { Deaf Access Simcoe } \\
\text { Muskoka }\end{array}$ \\
\hline Program areas: & $\begin{array}{l}\text { - } 50 \% \text { Services for } \\
\text { physically or mentally } \\
\text { challenged } \\
\text { - } 50 \% \text { Employment } \\
\text { preparation and } \\
\text { training }\end{array}$ & $\begin{array}{l}\text { - } 70 \% \text { Services for } \\
\text { physically or mentally } \\
\text { challenged } \\
\cdot 10 \% \text { Summer camps } \\
\cdot 10 \% \text { Public } \\
\text { education, other study } \\
\text { programs }\end{array}$ & $\begin{array}{l}-100 \% \text { Services for } \\
\text { physically or mentally } \\
\text { challenged }\end{array}$ \\
\hline Alberta & $\begin{array}{l}\text { Employabilities Society of } \\
\text { Alberta }\end{array}$ & Alberta Easter Seals Society & $\begin{array}{l}\text { Alberta Deaf Sports } \\
\text { Association }\end{array}$ \\
\hline Program areas: & $\begin{array}{l}\cdot 100 \% \text { Employment } \\
\text { preparation and } \\
\text { training (multi-disability) }\end{array}$ & $\begin{array}{l}-88 \% \text { Services for physically or } \\
\text { mentally challenged } \\
-12 \% \text { Housing for } \\
\text { seniors, low-income, and those } \\
\text { with disabilities }\end{array}$ & $\begin{array}{l}\text { - } 100 \% \text { Services for } \\
\text { physically or mentally } \\
\text { challenged }\end{array}$ \\
\hline
\end{tabular}

Source: Canada Revenue Agency. Charities listings. URL: http://www.cra-arc.gc.ca/chrts-gvng/lstngs/menu-eng.html [February 5, 2011].

\section{Disability Organizations and Capacity Issues}

\section{Context}

A significant percentage of the Canadian population has a disability. As shown in Table 2, almost $17 \%$ or 4.2 million Canadians have a disability. The rate is lowest in Alberta (15.8\%) and higher in Nova Scotia (23\%) and New Brunswick (19.8\%). The higher rates in the two Maritime provinces may be a reflection of the industrial base, with forestry and fishing activities being high risk occupations.

Persons with disabilities tend to be financially worse off than persons without disabilities. In a review of employment rates from 1993-2006, Crawford (2012) found persons with disabilities twice as likely to be unemployed when compared to those without disabilities, which, as he notes, has been long recognized by governments, disability organizations, and researchers alike (pp. 3-4). Similarly, the median total income for adults (15 years + ) with a disability is $69-73 \%$ that of those without disabilities, as shown in Table 2. The gap is noteworthy especially when one considers actual dollar figures. For example, in Newfoundland and Labrador, the total median income for an adult with disabilities in 2006 was $\$ 14,761$, which rose to $\$ 22,378$ in Alberta. Such financial disparities challenge one's ability to meet their needs given the additional costs they often face in dealing with their disability. For instance, two thirds of persons with disabilities use at least one assistive device (e.g., respiratory aids, computers, wheelchairs), $39 \%$ of whom report their needs are either not met or only partially met, largely due to financial considerations (Statistics Canada, 2010).

Family members are heavily relied upon for financial help in $70 \%$ of cases and for the 2.4 million adult persons with disabilities that require help in meeting their everyday needs (e.g., meal preparation, household chores, 
appointments), family members remain the primary caregivers in $83 \%$ of the cases (Statistics Canada, 2010). Such challenges limit the full inclusion of persons with disabilities into the work force, while increasingly challenging the time and resources of family members.

Table 2. Adults, median income of persons with disabilities (2006)

\begin{tabular}{lrrrr}
\hline & $\begin{array}{r}\text { Total } \\
\text { population } \\
(\text { No. })\end{array}$ & $\begin{array}{r}\text { Population persons } \\
\text { with disabilities } \\
\text { (No., \%) }\end{array}$ & $\begin{array}{r}\text { Median total } \\
\text { income adults } \\
15 \text { yrs+ without } \\
\text { disability }(\$)\end{array}$ & $\begin{array}{r}\text { Median total income } \\
\text { adults 15yrs+ with } \\
\text { disability (\$, \%) }\end{array}$ \\
\hline Canada & $25,422,280$ & $4,215,520(16.6)$ & 27,496 & $19,199(70)$ \\
$\begin{array}{l}\text { Newfoundland } \\
\text { and Labrador }\end{array}$ & 421,190 & $71,500(17)$ & 21,213 & $14,761(70)$ \\
$\begin{array}{l}\text { Nova Scotia } \\
\text { New Brunswick }\end{array}$ & 750,240 & $172,570(23)$ & 24,959 & $18,231(73)$ \\
& 595,480 & $117,860(19.8)$ & 24,337 & $16,796(69)$ \\
Ontario & $9,777,220$ & $1,770,760(18.1)$ & 29,326 & $20,955(71)$ \\
Alberta & $2,596,410$ & $410,600(15.8)$ & 30,525 & $22,378(73)$ \\
\hline
\end{tabular}

Source: Statistics Canada. (2007). Participation and activity limitation survey 2006. URL: http://www.statcan.gc.ca/cgibin/imdb/p2SV.pl?Function=getSurvey\&SDDS=3251\&lang $=$ en \&db=imdb\&adm $=8 \&$ dis $=2$ [February 5, 2011].

\section{Human resources}

Overall, two points emerge along the human dimension of disability organizations selected for the study as shown in Table 3. First, there are a higher number of full-time workers in the disability organizations in the have provinces, suggesting that these organizations are simply larger in size. However, when population differences are taken into consideration, one observes a higher rate of full-time employment per capita in the have not provinces. This suggests more people are required to deliver needed services, perhaps due to a sparse population spread out over a larger geographical area than in the have not provinces. A similar situation exists in relation to part-time workers, though not to the same degree. The exception to this pattern is New Brunswick where we find the greatest number of part-time workers in disability organizations. As we will see in the next section, this is part of a larger funding challenge facing disability organizations in New Brunswick who have increasingly turned to part-time workers to carry much of the workload. 
Table 3. Human resources, 5-year average (2005-2010)

\begin{tabular}{|c|c|c|c|c|c|c|}
\hline \multirow[b]{2}{*}{ Province } & \multicolumn{3}{|c|}{ Full-Time } & \multicolumn{3}{|c|}{ Part-Time } \\
\hline & $\begin{array}{c}\text { Number } \\
\text { of } \\
\text { staff } \\
\end{array}$ & $\begin{array}{c}\text { Average } \\
\text { wages (\$) }\end{array}$ & $\begin{array}{l}\text { Per capita } \\
\text { wages }(\$)\end{array}$ & $\begin{array}{c}\text { Number } \\
\text { of } \\
\text { staff } \\
\end{array}$ & $\begin{array}{c}\text { Average } \\
\text { wages (\$) }\end{array}$ & $\begin{array}{l}\text { Per capita } \\
\text { wages }(\$)\end{array}$ \\
\hline \multicolumn{7}{|c|}{ Have-not provinces } \\
\hline $\begin{array}{l}\text { Newfoundland } \\
\text { and Labrador }\end{array}$ & 4 & 32,041 & 0.25 & 3 & 2,922 & 0.02 \\
\hline Nova Scotia & 9 & 45,368 & 0.44 & 13 & 4,553 & 0.06 \\
\hline \multicolumn{7}{|l|}{ New Brunswick } \\
\hline \multirow[t]{2}{*}{ Average } & 11 & 26,251 & 0.39 & 30 & 3,651 & 0.15 \\
\hline & 8 & 34,385 & 0.13 & 15 & 3,944 & 0.03 \\
\hline \multicolumn{7}{|l|}{ Have provinces } \\
\hline Ontario & 29 & 54,841 & 0.004 & 23 & 19,135 & 0.001 \\
\hline \multirow{2}{*}{$\begin{array}{l}\text { Alberta } \\
\qquad \text { Average }\end{array}$} & 20 & 46,284 & 0.01 & 23 & 8,197 & 0.002 \\
\hline & 25 & 50,322 & 0.003 & 23 & 13,666 & 0.001 \\
\hline
\end{tabular}

Note: Information derived from Section C and/or Schedule 3 of the Registered Charity Information Return. Averages and per capita calculations computed by author using population data from: Statistics Canada. (2011). Population by year, by province and territory. CANSIM, Table 051-0001. URL: http://www40.statcan.ca/101/cst01/demo02a-eng.htm [February 5, 2011].

The second point to be observed is that full-time employees are on average better paid in the have provinces $(\$ 50,322$ compared to $\$ 34,385)$. The five-year average yearly full-time wages are highest in Ontario $(\$ 54,841)$ and lowest in New Brunswick $(\$ 26,251)$. When broken down on a per capita basis and similar to employment numbers above, we find on average a higher level of remuneration in the have not provinces $(\$ 0.13)$ when compared to the have provinces (\$0.003). This is a wage difference of up to 43 times larger in the have not provinces (with Nova Scotia an outlier). Part-time workers in the have provinces are also on average better paid than their counterparts in the have not provinces as shown in Table 3.

However, such comparisons may mask important cost-of-living differences across provinces. To address this, wages for employees in disability organizations are compared to the average wage for each province-we find that the full-time five-year average compensation for employees in disability organizations for all provinces is higher than their respective provincial average earnings of workers except for those workers in New Brunswick whose five-year average for full-time workers is approximately $\$ 2,000$ less than the 2006 Census Canada provincial average (compare figures in Table 3 and Table 4). Moreover, the variation in the magnitude of the difference in wages for full-time workers is similar across provinces, suggesting similar cost-of-living effects, thus providing some confidence in the interprovincial comparisons as shown in Table 4 (with New Brunswick as the outlier). The above trends hold at the sectoral level. ${ }^{1}$ 


\section{Table 4. Average earnings of the population 15 years \& over (2006)}

\begin{tabular}{|c|c|c|}
\hline Province & $\begin{array}{l}\text { Average earnings } \\
\text { (\$) }\end{array}$ & $\begin{array}{l}\text { Average earnings as } \% \text { of } \\
\text { average provincial } \\
\text { disability organization }\end{array}$ \\
\hline \multicolumn{3}{|l|}{ Have not provinces } \\
\hline $\begin{array}{l}\text { Newfoundland and } \\
\text { Labrador }\end{array}$ & 27,636 & 86.3 \\
\hline Nova Scotia & 30,187 & \multirow{3}{*}{$\begin{array}{c}66.5 \\
108.4\end{array}$} \\
\hline New Brunswick & 28,450 & \\
\hline Average & 28,758 & \\
\hline \multicolumn{3}{|l|}{ Have provinces } \\
\hline Ontario & 38,099 & 69.5 \\
\hline \multirow[t]{2}{*}{ Alberta } & 42,233 & \multirow[t]{2}{*}{91.2} \\
\hline & 40,166 & \\
\hline Canada & 35,498 & \\
\hline
\end{tabular}

Source: Statistics Canada. (2007). 2006 Census. URL: http://www40.statcan.gc.ca/101/ cst01/labor50a-eng.htm [April 15, 2011].

\section{Financial resources}

Measures of the financial capacity of disability organizations are their liquidity, revenue dependency, and main expenditures. Liquidity is a measure of an organization's ability to turn assets into cash quickly to meet shortterm obligations. This is captured by the Quick Ratio (QR) and is calculated by dividing an organization's current assets (cash + receivables) by their current liabilities (debt + payables) (Bragg, 2006). A ratio of less than "1" (e.g., 0.75) means that an organization would be unable to meet its short-term obligations if they came due all at once (e.g., it would only be able to meet $75 \%$ of its short-term obligations) and is an indication that the organization is not in good financial health.

Quick Ratios calculated for the disability organizations studied in the five provinces show that all but one (discussed further below) are in good financial health in a liquidity sense. In the have not provinces, QRs range from 2.11 in Nova Scotia and 3.87 in New Brunswick to a high of 22.43 in Newfoundland and Labrador. ${ }^{2}$ Similarly, in the have provinces, QRs range from 4.45 in Ontario to 9.39 in Alberta. Overall, the have provinces are on average in a slightly better financial position than have not provinces (average QRs of 5.79 and 4.42 respectively) and both meet industry standards (Jackson \& Fogarty, 2005).

Selected revenue streams for the disability organizations studied are profiled in Table 5. The results reveal some major differences between the have and have not provinces. On average and on a per capita basis, have not provinces are twice as dependent on revenues from provincial governments ( $\$ 0.09$ vs. $\$ 0.05$ per person) with funding from other levels of government limited. Combined with the fact disability organizations in the have not provinces are seven times more dependent on revenues from the sale of goods and services $(\$ 0.07$ vs. $\$ 0.01$ per person) and are three times more dependent on revenue from fundraising ( $\$ 0.11$ vs. $\$ 0.04$ per person), these organizations face a challenging endeavour in servicing their customers. The very people these organizations are expected to serve are expected to shoulder a significantly larger fraction of the costs of the services-all in geographical areas that are traditionally financially challenged. This may explain the heavier 
reliance on the provincial government for revenues and underscores the importance of equalization payments to the have not provinces.

\section{Table 5. Revenue stream profile (\$) for disability organizations reviewed, 5-year average (2005-2010)}

\begin{tabular}{|c|c|c|c|c|c|c|c|}
\hline Province & $\begin{array}{c}\text { Charitable } \\
\text { receipts }\end{array}$ & $\begin{array}{c}\text { Federal } \\
\text { government }\end{array}$ & $\begin{array}{l}\text { Provincial } \\
\text { government }\end{array}$ & $\begin{array}{l}\text { Municipal } \\
\text { government }\end{array}$ & $\begin{array}{c}\text { From } \\
\text { other } \\
\text { charities }\end{array}$ & $\begin{array}{c}\text { Sale of } \\
\text { goods/ } \\
\text { Services }\end{array}$ & $\begin{array}{l}\text { Fund- } \\
\text { raising }\end{array}$ \\
\hline \multicolumn{8}{|c|}{ Have not provinces } \\
\hline $\begin{array}{l}\text { Newfoundland } \\
\text { and Labrador }\end{array}$ & 14,220 & 35,908 & 24,931 & --- & 963 & 472 & 633,415 \\
\hline Nova Scotia & 111,537 & 10,051 & 246,075 & 16,555 & 40,930 & 176,567 & 105,337 \\
\hline New Brunswick & 44,417 & 48,285 & 312,296 & 481 & 16,346 & 261,327 & 10,095 \\
\hline $\begin{array}{r}\text { Average } \\
\text { (per capita) }\end{array}$ & $\begin{array}{r}56,725 \\
(0.09)\end{array}$ & $\begin{array}{r}31,415 \\
(0.01)\end{array}$ & $\begin{array}{r}194,254 \\
(0.09)\end{array}$ & $\begin{array}{l}5,679 \\
(0.00)\end{array}$ & $\begin{array}{r}19,413 \\
(0.01)\end{array}$ & $\begin{array}{r}146,122 \\
(0.07)\end{array}$ & $\begin{array}{r}249,616 \\
(0.11)\end{array}$ \\
\hline \multicolumn{8}{|l|}{ Have provinces } \\
\hline Ontario & $2,280,456$ & 246,635 & 668,385 & 75,045 & 100,504 & 48,038 & $1,084,897$ \\
\hline Alberta & 496,157 & 92,883 & 991,548 & 2,710 & 100,765 & 140,098 & 188,921 \\
\hline $\begin{array}{r}\text { Average } \\
\text { (per capita) }\end{array}$ & $\begin{array}{r}1,388,307 \\
(0.08) \\
\end{array}$ & $\begin{array}{r}169,759 \\
(0.01) \\
\end{array}$ & $\begin{array}{r}829,967 \\
(0.05) \\
\end{array}$ & $\begin{array}{r}38,877 \\
(0.00) \\
\end{array}$ & $\begin{array}{r}100,635 \\
(0.01) \\
\end{array}$ & $\begin{array}{r}94,068 \\
(0.01) \\
\end{array}$ & $\begin{array}{r}636,909 \\
(0.04) \\
\end{array}$ \\
\hline
\end{tabular}

Source: Canada Revenue Agency. Charities listings. URL: http://www.cra-arc.gc.ca/chrts-gvng/lstngs/menu-eng.html [February 5, 2011]. Calculations (averages, per capita) made by author.

Expenditures are profiled in Table 6. They show that on average on a per capita basis, expenditures are significantly greater in the have not provinces. This may be related to the greater need for disability services given the higher rate of persons with disabilities in those provinces. It also places a larger financial stress on disability organizations to deliver the needed services, something for which those utilizing the services are expected to pay a larger share, as noted above.

Lastly, the fundraising ratio was calculated based on the dollars raised versus the costs spent on fundraising efforts. On average and on the whole, as Table 6 shows, have not provinces are much better at fundraising than have provinces, raising $\$ 1.43$ versus $\$ 1.09$ in revenues for every dollar spent of fundraising. However, note the wide variations, which may be due to a number of factors. For instance, organizational size matters, with smaller organizations tending to report increases in charitable receipts less often (Nonprofit Research Collaborative, 2012), perhaps due to the fact that on average they expect to face higher overhead cost ratios when compared to large organizations (Association of Fundraising Professionals, 2008). Much also depends on an organization's infrastructure, such as donor databases and dedicated fundraising staff (Ketchum Canada Inc., 2009). Fundraising ratios will also be affected by the type of fundraising event and time of year that the event is held (Canada Revenue Agency, 2009). It is because of these factors that many recommend the need to use three- to five-year rolling fundraising ratio averages, as well as other financial details, to obtain a fuller picture, as this article demonstrates.

These results are consistent with surveys on giving, volunteering, and participating (Statistics Canada, 2004a). Disability organizations are part of the broader social service organization category. Organizations within this category typically attract high donor rates, but experience low donation values (Heinz, 2001; Statistics Canada, 
2006, 2009). Even so, fundraising efforts are considered poor, given that fundraising costs account for $70 \%$ or more of funds raised (see Canada Revenue Agency, 2009; Greenfield, 1999), something for which much work has been devoted to correcting through standards development among other things (Imagine Canada, 2011). Moreover, these results may be due to insufficient core infrastructure such as full-time employees, as shown above, and technological dimensions examined below (for a fuller discussion, see National Center for Charitable Statistics, 2005).

The above financial dimension trends for quick ratios, revenue streams, and expenditures are, on the whole, generally consistent at the sectoral level (see Note 1).

\section{Table 6. Expenditure profile for disability organizations reviewed, 5-year average (2005-2010). Totals (\$), (per capita)}

\begin{tabular}{|c|c|c|c|c|c|}
\hline Province & $\begin{array}{c}\text { Total } \\
\text { per capita }\end{array}$ & $\begin{array}{l}\text { Total on } \\
\text { programs }\end{array}$ & $\begin{array}{c}\text { Total on } \\
\text { management } \\
\text { and } \\
\text { administration }\end{array}$ & $\begin{array}{l}\text { Total on } \\
\text { fundraising }\end{array}$ & $\begin{array}{l}\text { Fundraising } \\
\text { ratio }\end{array}$ \\
\hline \multicolumn{6}{|l|}{ Have not Provinces } \\
\hline $\begin{array}{l}\text { Newfoundland } \\
\text { and Labrador }\end{array}$ & $\begin{array}{c}715,912 \\
(1.41)\end{array}$ & 130,747 & 166,269 & 406,668 & 1.56 \\
\hline Nova Scotia & $\begin{array}{c}1,095,375 \\
(1.17)\end{array}$ & 869,503 & 90,606 & 88,005 & 1.20 \\
\hline New Brunswick & $\begin{array}{c}720,432 \\
(0.96) \\
\end{array}$ & 574,607 & 110,033 & 29,279 & 0.34 \\
\hline $\begin{array}{r}\text { Average } \\
\text { (per capita) }\end{array}$ & $\begin{array}{c}843,906 \\
(0.38)\end{array}$ & $\begin{array}{c}524,952 \\
(0.24)\end{array}$ & $\begin{array}{c}122,303 \\
(0.06)\end{array}$ & $\begin{array}{c}174,651 \\
(0.08)\end{array}$ & 1.43 \\
\hline \multicolumn{6}{|l|}{ Have Provinces } \\
\hline Ontario & $\begin{array}{c}4,986,954 \\
(0.39)\end{array}$ & $3,777,234$ & 300,702 & 860,576 & 1.26 \\
\hline \multirow[b]{2}{*}{$\begin{array}{r}\text { Average } \\
\text { (per capita) }\end{array}$} & $\begin{array}{c}2,310,814 \\
(0.64)\end{array}$ & $1,573,643$ & 443,856 & 309,245 & 0.61 \\
\hline & $\begin{array}{c}3,648,884 \\
(0.22)\end{array}$ & $\begin{array}{c}2,675,439 \\
(0.16) \\
\end{array}$ & $\begin{array}{c}372,279 \\
(0.02) \\
\end{array}$ & $\begin{array}{c}584,911 \\
(0.04) \\
\end{array}$ & 1.09 \\
\hline
\end{tabular}

Source: Canada Revenue Agency. Charities listings. URL: http://www.cra-arc.gc.ca/chrts-gvng//stngs/menu-eng.html [February 5, 2011]. Calculations (averages, per capita) made by author.

\section{Technological resources}

Technological resources are capital assets that include equipment, vehicles, computers, furniture, and fixtures. They do not include land and buildings. Taking stock of these items provides an indication of the tools in an organization's possession available to carry out their work. As Table 7 shows, have not provinces are on average and across all sectors more heavily invested in technological aspects $(\$ 61,985$ compared to $\$ 48,664)$ though some variation occurs across the sectors. Whether this is a good indication is debatable. For instance, the results suggest have not provinces have the tools to "do the job"; yet, this is deceiving given the sectoral differences. Moreover, have provinces may be renting equipment and furniture, which would not show up under this category since they would not own the material. One must also consider the fact that rental options may not 
be available in the more sparsely populated have not provinces, thereby necessitating the purchase of equipment and further challenging the financial capacities of disability organizations in these provinces. When monies are tied up in capital assets, fewer resources are available for programs.

Table 7. Investment in technology (e.g., equipment, computers, vehicles, furniture), 5-year average (2005-2010). Sectoral Data (\$), (per capita)

\begin{tabular}{|c|c|c|c|c|}
\hline Province & $\begin{array}{c}\text { Employment } \\
\text { services }\end{array}$ & $\begin{array}{c}\text { Assistive } \\
\text { devices }\end{array}$ & $\begin{array}{l}\text { Hearing } \\
\text { services }\end{array}$ & $\begin{array}{c}\text { Overall } \\
\text { summary }\end{array}$ \\
\hline \multicolumn{5}{|l|}{ Have not provinces } \\
\hline Newfoundland and Labrador & --- & 6,586 & 144,039 & 50,208 \\
\hline Nova Scotia & 11,752 & 57,097 & 43,679 & 37,509 \\
\hline \multirow[t]{2}{*}{ New Brunswick } & 292,513 & 2,202 & --- & 98,238 \\
\hline & $\begin{array}{c}101,422 \\
(0.05)\end{array}$ & $\begin{array}{l}21,962 \\
(0.01)\end{array}$ & $\begin{array}{l}62,573 \\
(0.03)\end{array}$ & $\begin{array}{l}61,985 \\
(0.03)\end{array}$ \\
\hline \multicolumn{5}{|l|}{ Have provinces } \\
\hline Ontario & 56,732 & --- & 3,850 & 20,194 \\
\hline \multirow[t]{2}{*}{ Alberta } & 174,702 & 55,569 & 1,135 & 77,135 \\
\hline & $\begin{array}{c}115,717 \\
(0.01) \\
\end{array}$ & $\begin{array}{l}27,785 \\
(0.00) \\
\end{array}$ & $\begin{array}{l}2,492 \\
(0.00) \\
\end{array}$ & $\begin{array}{l}48,664 \\
(0.00) \\
\end{array}$ \\
\hline
\end{tabular}

Source: Canada Revenue Agency. Charities listings. URL: http://www.cra-arc.gc.ca/chrts-gvng/lstngs/menu-eng.html [February 5, 2011]. Calculations (averages, totals, ratios) made by author.

\section{CONGRUENCE WITH INTERVIEW DATA}

The results above paint a mixed picture. Disability organizations are limited in their capacity to offer innovative programming without funds to cover core operating expenses such as staffing. While, in the aggregate, they are able to meet their short-term financial needs, expenditures are significant especially for those in the have not provinces, who depend greatly on revenues from the sale of their goods and services and from fundraising efforts. This places an extra burden on the very people who need and use the services and on the need to continually seek out funds. This suggests that disability organizations are "holding their own" but that they lack the ability to undertake long-term strategic planning, thereby hampering the potential development and delivery of innovative programming. These results are consistent with a 2003 Canadian Council on Social Development report that documented the tenuous position confronting nonprofits and voluntary organizations (Canadian Council on Social Development, 2003), as well as the 2004 National Survey on Nonprofits and Voluntary Organizations (Statistics Canada, 2004b), which came to similar conclusions, and suggests little has changed.

These results were reinforced through interviews conducted with officials from these organizations after the quantitative analysis was completed. Indeed, human resources proved to be a significant challenge due to the lack of steady funding for core operating costs. Note that funding was largely based on a per project basis and while an allowance was built in for overhead costs, all officials interviewed stated that the actual dollars received were meagre and did not truly cover costs. More problematic is the fact that disability organizations do not receive payment unless a successful outcome is achieved such as continuous employment for a prolonged period of time (Agency officials $4 \& 5$ ). This places an added burden on disability organizations to "find" funds to cover costs incurred in such situations and underscores the importance of recipient selection. Given such risks, 
disability organizations have increasingly turned to the practice of "creaming"-serving only those people who will likely succeed, as narrowly defined by governments, and not necessarily those people most in need of the service (Agency officials $4 \& 6$ ).

Funding challenges also accentuate staffing issues. As one agency official stated, it really made it hard to attract staff given the short-term nature of positions (e.g., seven months) and the lack of benefits, and noted the high turnover in staff in nonprofits (Agency official 1). This same official lamented that even hirings for specific projects were challenging, given that many funding bodies disqualified those who had previously worked or volunteered for the organization. Not all disability organizations appear to experience such staffing challenges. For instance, some organizations in the have provinces noted they were fortunate in having low staff turnover. They attributed this to having "incredibly skilled" and flexible employees who could perform all positions in their organizations, thus facilitating their movement within organizations depending on changes in funding, as well as to making the organization a desirable and fun place to work (Agency officials 4 \& 5).

Capacity was also found to be lacking along technological dimensions. While project funds did offer some core operating funds for some basic needs on occasion, such as for photocopies and a laptop computer on one occasion, existing core operating funding did not cover technological needs (Agency official 1). Moreover, recognition and funding was required for the higher costs associated with meetings such as for sign language interpreters, large fonts, and Braille services. Such costs can quickly add up to $\$ 750-\$ 800$ per meeting before other costs such as for meeting space and technology (e.g., screens, projectors) (Agency official 2). It was also reported that technology deficits place a significant burden on disability organizations to seek out partnerships with businesses or other organizations to share equipment and space.

The result is that organizations increasingly turn to fundraising efforts and rely on revenues from the sale of goods and services to meet core operating expenses. Yet, all interviewees recognized the precarious position this places their organizations in, that is, if the organization's focus is on one major fundraising campaign or one or two services. If fewer funds are raised than expected, workers need to be let go or need to become part-time, which greatly increases the risk organizations face of losing them. Federal funding for specific projects also does not appear to be appealing. While funding opportunities are fewer and available funds smaller in nature, especially under the current Conservative government, funding is often short-term (e.g., six months to one year), cumbersome, difficult to access, and too specific in nature (e.g., targeted) (Agency officials 3 \& 6). A number of organizations are also unsure what sources of federal funding exist and have given up seeking federal funds given the plethora of changes undertaken at Service Canada in the past few years (Agency officials 3, 4, 5, \& 6).

The short-term nature of funding was particularly troublesome and as one official noted was a "waste of time and energy" given that you could barely get a program up and running and a few months or a year later you could not do it anymore as the funding for it terminated (Agency official 3). Put differently, "you can't train people [our clients] in less than one year to work" (Agency official 2). Agency officials were also pressured to "mainstream" programs; failing to do so meant they lost "innovation" funds, yet they felt that funding bodies lacked an understanding of the fact that programs were innovative for a reason-they did not fit the mainstream (Agency officials $4 \& 5$ ). Combined, these challenges have had the effect of making long-term strategic planning (e.g., five-year) very difficult and has left disability organizations in a constant state of "spinning their wheels" (Agency officials $1 \& 2$ ). 


\section{CONCLUSION}

This article examined one avenue for breaking the logjam between accountability and learning in order to unleash a round of programmatic innovation in relation to labour market programming for persons with disabilities: it examined the capacity of disability organizations in order to gauge their ability to provide innovative programs. Disability organizations have intimate knowledge of the needs of persons with disabilities yet seek stable long-term funding to meet their goals.

The conclusion that emerges from this investigation is that while disability organizations are relatively well positioned to deliver innovative programming, they are undermined by the lack of stable core operating funds, which have long been called for (e.g., Roberts, 2001). Broadly speaking, the figures suggest that disability organizations in the five provinces possess significant human resources. Remuneration for full-time workers is significantly higher than the provincial average earnings (except for New Brunswick). The results are even initially more favourable for the have not provinces where on a per capita basis, they seem to be better staffed with higher per capita average wages. Yet when one considers their sparse population dispersed over large territories, any potential human resource advantage may be negated, hence the need for a significant number of part-time workers, as was revealed. This suggests that disability organizations have a limited capacity to provide innovative programming without additional funding for core operating expenses such as for employees, a limitation that is felt more in the have not provinces.

Overall, the disability organizations studied are well able to meet their short-term financial obligations, with all organizations meeting the Quick Ratio standard. Of concern for disability organizations in the have not provinces is their significantly higher reliance on revenues from the people they serve through the sale of goods and services and on fundraising efforts as compared to the have provinces. However, the very people in these have not provinces that face the extra burden for paying for services, either through constant fundraising efforts or through service fees, is something many can ill afford, and something those in the have provinces do not face to the same degree. Given some of the financial challenges faced in the have not provinces, this places an added emphasis on government revenues. This underscores the importance of federal provincial transfers, which form a significant part of have not provinces revenues, up to $40 \%$ in Newfoundland and Labrador in some years and consistently between $28-35 \%$ in Nova Scotia and New Brunswick (calculations made from Statistics Canada [2004-2008] Public Sector Statistics). Funding parameters are also underscored by the fact that the have not provinces face greater expenditure costs (on average and per capita).

The net effect is the limits that the lack of core funding places on disability organizations' capacity to offer innovative programming; a point officials from these organizations emphasized and which is most acute in the have not provinces. If federal and provincial governments addressed this deficiency, it would allow disability organizations to more fully contribute in governance activities. As revealed in this examination, the federal government remains insignificant in terms of direct funding of disability organizations, even with the 2012 Economic Action Plan's proposed changes to the Opportunities Fund, which would see an additional \$30-million over three years available for disability programming (Government of Canada, 2012). ${ }^{3}$ While the increase in funding is welcomed, much more is needed to create an environment to spur innovation in order to significantly address the needs of persons with disabilities. This situation will likely remain unfulfilled given the current Conservative federal government's ideological disposition and priorities.

The above conclusions are a preliminary indication of the capacity that disability organizations in Canada possess, yet more work that examines a larger sample of disability organizations is required to ferret out capacity issues and funding mechanisms. In terms of funding mechanisms alone, research examining 
fundraising campaigns by charities may help reveal best practices guidelines to guide future fundraising efforts to help ensure their success. Such examination needs to be extended to disentangling differences in technological investments so as to help inform future charitable spending decisions. Such knowledge is important in that it will facilitate a fuller participation of disability organizations in governance activities.

\section{ACKNOWLEDGEMENTS}

This article was originally prepared for the 2011 Canadian Political Science Association Annual General Meetings, Wilfred Laurier University, Waterloo, Ontario, May 16-18. The author wishes to thank Rachel Laforest and Peter Graefe, and the journal's anonymous reviewers for their helpful comments.

\section{NOTES}

1. Detailed tables documenting sectoral data are not shown due to space limitations but are available from the author upon request.

2. For disability organizations profiled in Newfoundland and Labrador, their quick ratio of 22.43 is far beyond the desired standard of 1 or slightly higher. Such a high quick ratio figure is an indication of organizations having unproductive cash assets, that is, significant amounts of cash sitting in bank accounts that could be put to better use for the nonprofit (Jackson and Fogarty, 2005; Bowman, 2010). Further investigation is required to determine why this is so.

3. Included in the proposed changes to the Opportunities Fund was the plan to establish a panel to identify private sector successes and best practices for labour market participation for persons with disabilities.

\section{WEBSITE}

Canada Revenue Agency. Charities listings. URL: http://www.cra-arc.gc.ca/chrts-gvng//stngs/menu-eng.html

\section{REFERENCES / BIBLIOGRAPHIE}

Association of Fundraising Professionals. (2008). Measuring and reporting fundraising costs: A Canadian perspective. URL: http://www.afpnet.org/files/ContentDocuments/MeasuringandReporting FundraisingCosts\%20 June\%2008_1274302817015_2.pdf [July 15, 2012].

Bach, M. (2002). Governance regimes in disability-related policy and programs: A focus on community support systems. In A. Puttee (Ed.), Federalism, Democracy and Disability Policy in Canada (pp. 153-174). Kingston, ON: McGill-Queen's University Press.

Bakvis, H., Baier, G., \& Brown, D. (2009). Contested federalism: Certainty and ambiguity in the Canadian federation. Don Mills, ON: Oxford University Press.

Boismenu, G. (2006). Les nouveaux visages de vieux démons. Les défis posés au fédéralisme par la restruction de la protection sociale au Canada. Lien social et politiques, 56, 57-71.

Bowman, W. (2010). Asset composition. In B. A. Seaman, \& D. R. Young (Eds.), Handbook of research on nonprofit economics and management (pp. 69-82). Cheltenham, UK: Edward Elgar Publishing.

Bragg, S.M. (2006). Business ratios and formulas: A comprehensive guide. New York, NY: Wiley Publishers.

Brock, K. L. (2003). Delicate dances: New moves and old steps. In K. Brock (Ed.), Delicate dances. Public policy and the nonprofit sector (pp. 1-16). Montréal, QC: McGill-Queens University Press.

Bron, A. (2003). From an immigrant to a citizen: Language as a hindrance or a key to citizenship. International Journal of Lifelong Education, 22, 606-619.

Bull, C.N., \& Bane, S.D. (2001). Program development and innovation. Journal of Applied Gerontology, 20, 184-194. 
Burns, K.K., \& Gordon, G L. (2011). Analyzing the impact of disability legislation in Canada and the United States. Journal of Disability Policy Studies, 20, 205-218.

Canada Revenue Agency. (2003). Policy statement - political activities. URL: http://www.cra-arc.gc.ca/chrtsgvng/chrts/plcy/cps/cps-022-eng.html [September 12, 2012].

Canada Revenue Agency. (2009, June). Fundraising by registered charities - Guidance (CPS -028). URL: http://www.cra-arc.gc.ca/chrts-gvng/chrts/plcy/cps/cps-028-eng.html [March 12, 2011].

Canada Revenue Agency. (2011). What is a registered charity information return? URL: http://www.craarc.gc.ca/chrts-gvng/lstngs/2b-eng.html [March 12, 2011].

Canadian Centre on Disability Studies. (2002, May). Disability community capacity: A framework for preliminary assessment (Analysis Paper to HRDC, Social Policy Unit). URL: http://www.disabilitystudies.ca [January 15, 2011].

Canadian Council on Social Development. (2003). Summary report. Funding matters: The impact of Canada's new funding regime on nonprofit and voluntary organizations. URL: http://www.ccsd.ca/pubs/2003/fm/summary-fundingmatters.pdf [September 5, 2012].

Cardozo, A. (1996). Lion taming: Downsizing the opponents of downsizing. In G. Swimmer (Ed.), How Ottawa spends 1996-97: Life under the knife (pp. 303-336). Ottawa, ON: Carleton University Press.

Cloutier-Fisher, D., \& Skinner, M.W. (2004). Levelling the playing field? Exploring the implications of managed competition for voluntary sector providers of long-term care in small town Ontario. Health and Place, 12, 97-109.

Commission on the Future of Health Care in Canada. (2002). Building on values: The future of health care in Canada - Final Report. Cat. No. CP32-85/2002E-IN. URL: http://www.collectionscanada.gc.ca/webarchives /20071122004429/http://www.hc-sc.gc.ca/english/pdf/romanow/pdfs/hcc_final_report.pdf [September 28, 2012].

Crawford, C. (2012). Towards an understanding of effective practices in employment programs for people with disabilities in Canada. Toronto, ON: Institute for Research and Development on Inclusion and Society (IRIS). URL: http://irisinstitute.files.wordpress.com /2012/01/employment-program-best-practices_iris.pdf [July 15, 2012].

Damanpour, F., \& Schneider, M. (2009). Characteristics of innovation and innovation adoption in public organizations: Assessing the role of managers. Journal of Public Administration Research and Theory, 19(3): 495-522.

Desveaux, J.A., Lindquist, E.A., \& Toner, G. (1994). Organizing for policy innovation in public bureaucracy: AIDS, Energy and Environmental policy in Canada. Canadian Journal of Political Science, 27(3), 493-528.

Eakin, L. (2002). Supporting organizational infrastructure in the voluntary sector. A background paper prepared for the VSI Secretariat. URL: http://www.vsi-isbc. org/eng/products/reports.cfm [February 2, 2011].

Eldson, K., Reynolds, J., \& Steward, S. (1995). Voluntary organizations, citizenship and learning. Leicester, UK: NIACE.

Elson, P. (2011). High ideals and noble intentions: Voluntary sector-government relations in Canada. Toronto, ON: University of Toronto Press.

Finance Canada. (n.d.). Federal support to provinces and territories. URL: http://www.fin.gc.ca/fedprov/mtpeng.asp [May 31, 2011].

Friendly, M., \& White, L. (2008). From multilateralism to bilateralism to unilateralism in three short years: Child care in Canadian federalism. In H. Bakvis, \& G. Skogstad (Eds.), Canadian federalism: Performance, effectiveness, and legitimacy (pp. 182-204). Toronto, ON: Oxford University Press.

Golden, O. (1990). Innovation in public sector human services programs: The implications of innovation by 'groping along'. Journal of Policy Analysis and Management, 9(2), 219-248.

Gouthro, P.A. (2010). Grassroots and governance: Exploring informal learning opportunities to support active citizenship and community-based organizations within Canada. URL: http://www.cclcca.ca/ccl/

Research/FundedResearch/201009GouthroGrassroots.html [January 20, 2011].

Government of Canada. Department of Finance. (2012). Budget 2012: Budget plan. Ottawa, ON: Department of Finance. 
Government of Canada. Ministers Responsible for Social Services. (1997). Multilateral Framework on Employability Assistance for People with Disabilities. URL: http://www.socialunion.gc.ca/pwd/multi_e.html [January 5, 2011].

Government of Canada. (1998). À l'unisson: Une approche canadienne concernant les personnes handicapées. URL: http://www.socialunion.ca/pwd/unison/unison_f.html [January 6, 2011].

Government of Canada. (1999, February 4). A framework to improve the social union for Canadians. [News Release]. URL: http://www.socialunion.gc.ca/news/020499_e.html [March 6, 2011].

Government of Canada. (2003). Multilateral framework for labour market agreements for persons with disabilities. URL: http://www.socialunion.gc.ca/pwd/intro-multi2003_e.html [March 5, 2011].

Graefe, P., \& Levesque, M. (forthcoming). Accountability in labour market policies for persons with disabilities. In P. Graefe, J. Simmons, \& L. White, (Eds.), Intergovernmental Accountability in Canadian Social Policy. Toronto, ON: University of Toronto Press.

Graefe, P., \& Levesque, M. (2006). La nouvelle gouvernance fédérale et les politiques sociales au Canada: Leçons des ententes en matière de l'intégration en emploi des personnes ayant des handicaps. Lien social et politiques, 56, 75-88.

Graefe, P., \& Levesque, M. (2010). Accountability and funding as impediments to social policy innovation: Lessons from the Labour Market Agreements for Persons with Disabilities. Canadian Public Policy, 36, 45-62.

Graham, K.A., \& Phillips, S.D. (1997). Citizen engagement: Beyond the customer revolution. Canadian Public Administration, 40(2), 255-273.

Greenfield, J. (1999). Fund-raising: Evaluating and managing the fund development process (2nd ed.). Hoboken, NJ: John Wiley \& Sons Inc.

Hanes, R., \& Moscovitch, A. (2002). Disability supports and services in the Social Union. In A. Puttee (Ed.), Federalism, democracy and disability policy in Canada (pp. 121-152). Kingston, ON: McGill-Queen's University Press.

Harper, S. (2012, January 16). Interview by Peter Mansbridge, The National, CBC TV.

Heinz, L. (2001). Voluntary social service organizations in Canada: Public involvement and support. Canadian Centre for Philanthropy. URL: http://www.givingandvolunteering.ca/files/giving/en/n-r3.pdf [July 15, 2012].

Hendriks, C.M. (2006). When the forum meets interest politics: Strategic uses of public deliberation. Politics \& Society, 34, 571-602.

Human Resources Development Canada. (2002). Promising practices in Employability Assistance for People with Disabilities (EAPD) Funded programs and services. Final Report. Evaluation and Data Development Strategic Policy. SP-AH-196-08-02E. URL: http://publications.gc.ca/collections/Collection/RH63-2-196-0802E.pdf [August 2, 2012].

Human Resources and Social Development Canada. (n.d.). Opportunities fund for persons with disabilities. URL: http://www.hrsdc.gc.ca/eng/disability_issues/funding_programs/opportunities_fund/index.shtml [January 20, 2011].

Human Resources and Social Development Canada. (2008). Summative evaluation of the Opportunities Fund for Persons with Disabilities. Ottawa, ON: HRSDC. URL: http://www.hrsdc.gc.ca/eng/publications _resources/evaluation/2008/ofpd/sp_ah_923_11_09eng.pdf [July 12, 2012].

Imagine Canada. (2011). Standards for Canada's charities \& nonprofits. 2011 Pilot Standards. URL: http://www.imaginecanada.ca/files/www/en/standards/standards_imagine_canada_dec2011.pdf [September 05, 2012].

Jackson, P.M., \& Fogarty, T.E. (2005). Sarbanes-Oxley for nonprofits: A guide to gaining competitive advantage. Hoboken, NJ: John Wiley \& Sons Inc.

Ketchum Canada Inc. (2009). Trends. Philanthropic Trends Quarterly, 3, 1-7. 
Kroeger, A. (1996). Changing course: The federal government's program review of 1994-95. In A. Armit \& J. Bourgault, (Eds.), Hard choices or no choices (pp. 21-28). Toronto, ON: Institute of Public Administration of Canada.

Larner, W. (2000). Post welfare state governance: Towards a code of social and family responsibility. Social Politics, 7, 244-265.

Lazar, H. (Ed.). (1998). Canada: The state of the federation, 1997: Non-constitutional renewal. Kingston, ON: McGill Queen's University Press.

Lindquist, E. (2005). Organizing for mega-consultation: HRDC and the Social Security Reform. Canadian Public Administration, 48(3), 348-385.

Mansbridge, J.J. (1992). A deliberative theory of interest representation. In M. Patracca (Ed.), The politics of interests (pp. 32-57). San Francisco, CA: Westview Press.

Meadowcroft, J. (2004). Deliberative democracy. In R. F. Durant, D. J. Fiorino, \& R. O'Leary (Eds.), Environmental governance reconsidered: Challenges, choices, and opportunities (pp. 183-217). Cambridge, MA: The MIT Press.

Mook, L., Quarter, J., \& Ryan, S. (Eds.). (2010). Researching the social economy. Toronto, ON: University of Toronto Press.

Mulroy, E., \& Shay, S. (1997). Nonprofit organizations and innovation: A model of neighborhood-based collaboration to prevent child maltreatment. Social Work, 42(5), 515-524.

National Center for Charitable Statistics. (2005). Nonprofit overhead cost study. URL: http://nccsdataweb.urban.org/knowledgebase/index.php?category=40 [March 4, 2011].

Nonprofit Research Collaborative (NRC). (2012). Canadian nonprofit fundraising study. URL: http://www.afpnet.org/files/ContentDocuments/Canada-NRC-2012_FINAL.pdf [July 15, 2012].

Quarter, J., \& Mook, L. (2010). An interactive view of the social economy. Canadian Journal of Nonprofit and Social Economy Research, 1(1), 8-22.

Quarter, J., Mook, L., \& Armstrong, A. (2009). Understanding the social economy: A Canadian perspective. Toronto, ON: University of Toronto Press.

Panel on Accountability and Governance in the Voluntary Sector. (1999). Building on strength: Improving governance and accountability in Canada's voluntary sector. Final Report. URL: http://www.ecgi.org/ codes/documents/broadbent_report_1999_en.pdf [March 21, 2011].

Peter, E., Spalding, K., Kenny, N., Conrad, P., McKeever, P., \& Macfarlan, A. (2007). Neither seen nor heard: Children and homecare policy in Canada. Social Science \& Medicine, 64, 1624-1635.

Phillips, S. (2001). From charity to clarity: Reinventing government-voluntary sector relationships. In L.A. Pal (Ed.), How Ottawa spends 2001-2002: Power in transition, Don Mills, ON: Oxford University Press.

Phillips, S.D. (1995). The Liberals' mid-life crises: Aspirations versus achievements. In S. Phillips, (Ed.), How Ottawa spends 1995-96: Mid-life crises (pp. 1-30). Ottawa, ON: Carleton University Press.

Powers, L.E., Sowers, J., \& Singer, G.H.S. (2006). A cross-disability analysis of person-directed, long-term services. Journal of Disability Policy Studies, 17(2), 66-76.

Prince, M.J. (2004) Canadian disability policy: Still a hit-and-miss affair. Canadian Journal of Sociology, 29(1), 59-82.

Prince, M.J. (2010, April). Engaging in disability policy development and advocacy with the Canadian state. Paper presented at the Canadian Disability Policy Alliance meeting of CURA Partners, University of Regina, SK, Canada.

Putnam, R. D. (2000). Bowling alone: The collapse and revival of American community. New York, NY: Simon \& Schuster.

Rioux, M., \& Prince, M. J. (2002). The Canadian political landscape of disability: Policy perspectives, social status, interest groups and the rights movement. In A. Puttee (Ed.), Federalism, democracy and disability policy in Canada (pp. 11-28). Kingston, ON: McGill-Queen's University Press. 
Roberts, L. (2001). Caught in the middle: What small, non-profit organizations need to survive and flourish. Voluntary Sector Initiative Report. Voluntary Sector Secretariat. URL: http://www.vsiisbc.org/eng/products/reports.cfm [April 4, 2011].

Satterthwaite, S. B. (2002). Innovation and diffusion of managed care in Medicaid programs. State \& Local Government Review, 34(2), 116-126.

Statistics Canada. (2004a). Caring Canadians, involved Canadians: Highlights from the 2004 Canada Survey on Giving, Volunteering and Participating. Cat. No. 71-542-X1E. Ottawa, ON: Queen's Printer.

Statistics Canada. (2004b). Cornerstones of community: Highlights from the National Survey of Nonprofit and Voluntary Organizations. Cat. No. 61-533-XIE. Ottawa, ON: Queen's Printer.

Statistics Canada. (2007). Participation and activity limitation survey 2006. URL: http://www.statcan.gc.ca/cgibin/imdb/p2SV.pl?Function=getSurvey\&SD DS=3251\&lang=en\&db=imdb\&adm= 8\&dis=2 [February 5, 2011].

Statistics Canada. (2009). Caring Canadians, involved Canadians: Highlights from the 2007 Canada Survey of Giving, Volunteering and Participating. Minister of Industry. Cat:: 71-542-XPE. URL: http://www.givingandvolunteering.ca/files/giving/en/csgvp_highlights_2007.pdf [July 14, 2012].

Statistics Canada. (2004-2008). Public sector statistics. Cat. No. 68-213-x. Ottawa, ON: Minister of Industry. Statistics Canada. (2010). Participation and activity limitation survey 2006. Minister of Industry. URL: http:/l www23.statcan.gc.ca/imdb/p2SV.pl?Function=getSurvey\&SDDS=3251\&lang=en\&db=imdb\&adm=8\&dis= 2 [July 15, 2012].

Statistics Canada. (2011). Population by year, by province and territory. CANSIM, Table 051-0001. URL: http://www40.statcan.ca//01/cst01/demo02a-eng.htm [February 5, 2011].

Telford, H., Graefe, P., \& Banting, K. (2008). Defining the federal government's role in social policy: The spending power and other instruments. IRPP Policy Matters, 9(3), 108-123.

Treasury Board Secretariat. Government of Canada. Voluntary Sector Project Office. (2002). Guide to improving funding practices between the government of Canada and the voluntary sector. URL: http://www.vsiisbc.org/eng/products/reports.cfm [April 3, 2011].

Walker, J.L. (1969). The diffusion of innovations among the American states. American Political Science Review, 63, 880-899.

Weaver, C.L. (1994). Privatizing vocational rehabilitation options for increasing individual choice and enhancing competition. Journal of Disability Policy Studies, 5(1), 53-76.

White, D. (2005, November). New relations of welfare governance in Canada: Shifting the boundaries between state and civil society? Paper prepared for After Neo-liberalism? Consequences for citizenship, Workshop \#2 in the series Claiming Citizenship in the Americas, Université de Montréal, QC, Canada.

White, D. (2008, September). Can advocacy survive partnership? Representing the clients of the welfare state. Paper presented to the annual meeting of ISA RC19, Stockholm, Sweden.

Young, R.A. (1999). The struggle for Québec. Kingston, ON: McGill-Queen's University Press.

Zegans, M.D. (1992). Innovation in the well-functioning public agency. Public Productivity \& Management Review, 16(2), 141-156.

\section{ABOUT THE AUTHOR / L'AUTEUR}

Mario Levesque is Assistant Professor in the Department of Politics and International Relations at Mount Allison University. Email: malevesque@mta.ca 